\title{
Fungicide Rotation Programs for Managing Phytophthora Fruit Rot of Watermelon in Southeastern United States
}

\begin{abstract}
Chandrasekar (Shaker) S. Kousik, U.S. Vegetable Laboratory, USDA, ARS, Charleston, SC 29414; Pingsheng Ji, Department of Plant Pathology, University of Georgia, Tifton, GA 31793; Daniel S. Egel, Department of Botany and Plant Pathology, Purdue University, West Lafayette, IN 47907; and Lina M. Quesada-Ocampo, Department of Plant Pathology, North Carolina State University, Raleigh, NC 27695
\end{abstract}

Accepted for publication 23 January 2017.

\begin{abstract}
About $50 \%$ of the watermelons in the United States are produced in the southeastern states, where optimal conditions for development of Phytophthora fruit rot prevail. Phytophthora fruit rot significantly limits watermelon production by causing serious yield losses before and after fruit harvest. Efficacy of fungicide rotation programs and Melcast-scheduled sprays for managing Phytophthora fruit rot was determined by conducting experiments in Phytophthora capsici-infested fields at three locations in southeastern United States (North Carolina, South Carolina, and Georgia). The mini seedless cultivar Wonder and seeded cultivar Mickey Lee (pollenizer) were used. Five weekly applications of fungicides were made at all locations. Significant fruit rot (53 to 91\%, mean 68\%) was observed in the nontreated control plots in all three years

(2013 to 2015) and across locations. All fungicide rotation programs significantly reduced Phytophthora fruit rot compared with nontreated controls. Overall, the rotation of Zampro alternated with Orondis was highly effective across three locations and two years. Rotations of Actigard followed by Ranman + Ridomil Gold, Presidio, V-10208, and Orondis, or rotation of Revus alternated with Presidio were similarly effective. Use of Melcast, a melon disease-forecasting tool, may occasionally enable savings of one spray application without significantly impacting control. Although many fungicides are available for use in rotations, under very heavy rain and pathogen pressure, the fungicides alone may not offer adequate protection; therefore, an integrated approach should be used with other management options including well-drained fields.
\end{abstract}

Phytophthora capsici, the causal agent of Phytophthora fruit rot of watermelon and other cucurbits, is responsible for serious preand postharvest yield and quality losses in the production of watermelon, as well as a number of other important vegetable crops in the United States (Kousik et al. 2014a, 2016). The pathogen causes crown and root rot, leaf blight, plant wilt, and fruit rot on various vegetable crops (Erwin and Riberio 1996; Granke et al. 2012; Hausbeck and Lamour 2004; Keinath et al. 2007). In watermelon, fruit rot is often the most damaging symptom. It begins as a dark, water-soaked, depressed lesion that expands quickly along with powdery, wet mold progressively developing over the infected area and eventually the entire fruit rots. The disease is very prevalent on watermelon crop in the southeastern states (Florida, Georgia, South Carolina, North Carolina, and Virginia) and more recently in other parts of the United States (e.g., Michigan, Delaware, Maryland, and Indiana) (Kousik et al. 2016). A significant portion of U.S. watermelon production occurs in the southeastern states where environmental conditions favorable for fruit rot development occur regularly during the growing season. In 2015 , more than 21,853 ha $(54,000$ acres) of watermelon were planted in the southeast, with Florida (8,700 ha), Georgia (7,891 ha), South Carolina (3,116 ha) and North Carolina (2,387 ha) (USDA, NASS survey, 2015) being the leading states where Phytophthora fruit rot was an important concern for many growers. Identifying effective ways to manage Phytophthora

Corresponding author: C. S. Kousik (Shaker); E-mail: shaker.kousik@ars.usda.gov

This article is in the public domain and not copyrightable. It may be freely reprinted with customary crediting of the source. The American Phytopathological Society, 2017. fruit rot has been considered a high priority since 2013 and before by the National Watermelon Association (NWA) (Kousik et al. 2014a; 2016; Morrissey 2006; B. Morrissey, 2013, 2014 and 2015, personal communication). Research conducted in North and South Carolina from 2006 to 2013 identified several fungicides (e.g., Revus, Presidio, Zampro, Orondis, and Forum) that are effective for managing pre- and postharvest phases of Phytophthora fruit rot of watermelon (Kousik et al. 2011, 2014a). However, the prevalence of pathogen resistance to chemicals such as Ridomil and Ranman has been well documented for P. capsici (Hausbeck and Lamour 2004; Jackson et al. 2012; Kousik and Keinath 2008; Lamour and Hausbeck 2000; Lamour and Keinath 2007; Parra and Ristaino 2001). Commercial watermelon cultivars with resistance to fruit rot are not yet available; but resistant germplasm lines have been identified and developed for use in breeding programs (Kousik et al. 2012, 2014c); therefore, application of effective fungicides continues to be a major component in developing effective programs for managing this disease.

The objectives of the present study were to compare and develop fungicide rotation programs that watermelon growers can adapt in their overall disease management plans especially in areas where Phytophthora fruit rot has been a severe problem year after year. In addition, Melcast, a melon disease forecaster that bases spray thresholds on environmental favorability index (EFI) was used as a tool to schedule spray applications. Melcast uses daily weather data for a given location using periods of temperature and humidity/ leaf wetness that are favorable for development of foliar diseases on watermelon and melon (Latin and Egel 2001). The use Melcast as a specific treatments was included to determine if we could obtain improved control or reduce the number of sprays needed for managing Phytophthora fruit rot of watermelon. 
Planting and Fungicide Rotations

Experiments to evaluate the effect of fungicide rotations and Melcast-based spray applications on development of Phytophthora fruit rot of watermelon were conducted in $P$. capsici-infested fields at three locations in southeastern United States. The locations were: the U.S. Vegetable Laboratory farm in Charleston, SC; the University of Georgia, Coastal Plain Experiment Station farm in Tifton, GA; and the North Carolina State University, Horticultural Crops Research Station in Kinston, NC. Most of the techniques used to conduct these experiments have been described before (Kousik et al. 2011; 2014a).

The experimental design was a randomized complete block with 4 replications in all locations. Four- to five-week-old seedlings of the susceptible seedless (triploid) cultivar Wonder and the susceptible diploid (seeded, pollenizer) cultivar Mickey Lee were transplanted onto raised beds. There were 12 plants per plot with every fourth plant in the plot being Mickey Lee, which served as the pollenizer at all three locations. In South Carolina, the raised beds were $48 \mathrm{~cm}$ wide and $20 \mathrm{~cm}$ high. Beds were spaced $6.4 \mathrm{~m}(21 \mathrm{ft})$ apart and covered with silver plastic mulch. Plots were a single row of 12 plants spaced $46 \mathrm{~cm}$ apart with 4.6-m spacing between plots. Plants were irrigated as needed using drip irrigation with a drip tape placed $2.5 \mathrm{~cm}$ below the plastic mulch. After bedding but before planting, row middles were sprayed with Roundup Pro (1.17 liter/ha) and Strategy (2.24 liter/ha) for weed management. During the growing season, weeds between beds were controlled with spot application of Roundup or hand weeding. In Georgia, the raised plant beds were $76 \mathrm{~cm}$ (30 inches) wide and $15 \mathrm{~cm}$ (6 inches) high and were spaced 1.8 meters $(6 \mathrm{ft})$ apart. The raised beds were covered with silver reflective mulch with a single drip tape installed $2.5 \mathrm{~cm}$ below the surface in the center of the beds for irrigation.

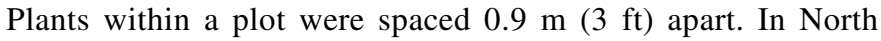
Carolina, plots were bare-ground with double-row raised beds that were $20.3 \mathrm{~cm}$ ( 8 inches) high on $1.06 \mathrm{~m}$ (42-inch) centers with plots

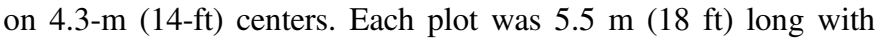
$3 \mathrm{~m}(10 \mathrm{ft})$ between plots. Plants within a plot were spaced $0.9 \mathrm{~m}$ (3 ft) apart. Standard production practices for watermelon for the southeast were followed at all locations (Kemble 2015; Sanders 2006). Details of planting, inoculation, initiation of sprays, and observation dates are provided in Table 1.
The details of the fungicides applied at the three locations, their formulations, active ingredients, and rate are presented in Table 2. During each year and at each location, there were a total of five sprays per season. In 2013, trials were conducted in South Carolina and Georgia. Five simple rotation programs and a tank mix of Ranman and Ridomil were evaluated. In addition, Ridomil Gold was used as the standard treatment and nontreated plots as the controls. In 2014, the following fungicide rotations were evaluated in three states: (i) Actigard/K-Phite/Revus/Presidio/Zampro; (ii) Forum/Presidio/ Phosphite/Ranman + Ridomil/Revus; (iii) Actigard/Ranman + Ridomil/ Presidio/V10208/ Orondis; (iv) Forum/K-Phite /Presidio/Zampro/ Ranman; (v) Zampro with Orondis; (vi) Melcast based spray of most effective fungicides in rotation (Presidio, Ranman + Ridomil, Revus, Zampro, Orondis); (vii) Ridomil Gold (standard treatment); and (viii) nontreated control. In addition, in South Carolina, Revus alternated with Presidio was included because of previous documented efficacy (Kousik et al. 2014a). Similarly, in North Carolina, Revus alternated with Ridomil Gold was included as a standard rotation scheme. In 2015, four of the most effective fungicide rotation programs from 2014, as well as nontreated control and the standard treatment (Ridomil Gold) were evaluated in Georgia. All the rotation programs from 2014 and the controls were evaluated in South Carolina in 2015.

Fungicide treatments were applied using a $\mathrm{CO}_{2}$-pressurized backpack sprayer with a hand- held boom at all three locations. In South Carolina, the sprayer was equipped with 3 nozzles (flat fan, 8002 VS; Teejet, Wheaton, IL) spaced $48 \mathrm{~cm}$ apart and calibrated to deliver 290 liters/ha. Similarly in North Carolina, the sprayer was equipped with 3 hollow-cone nozzles (TXVS-26) spaced $48 \mathrm{~cm}$ apart and calibrated to deliver 421 liters/ha. In Georgia, the sprayer was equipped with 2 nozzles (flat fan, Teejet 8005E SS) spaced $48 \mathrm{~cm}$ apart and calibrated to deliver 327 liters/ha. The first fungicide application was made when most of the watermelon fruit were about 8 to $10 \mathrm{~cm}$ in diameter. The first applications were started at this stage as this was when most fruit came in contact with the ground. In addition, watermelon fruit are susceptible to $P$. capsici at all developmental stages (Ando et al. 2009; Kousik et al. 2014b), hence subsequent applications were made at weekly intervals at all locations (Table 1). In South Carolina, the fungicide

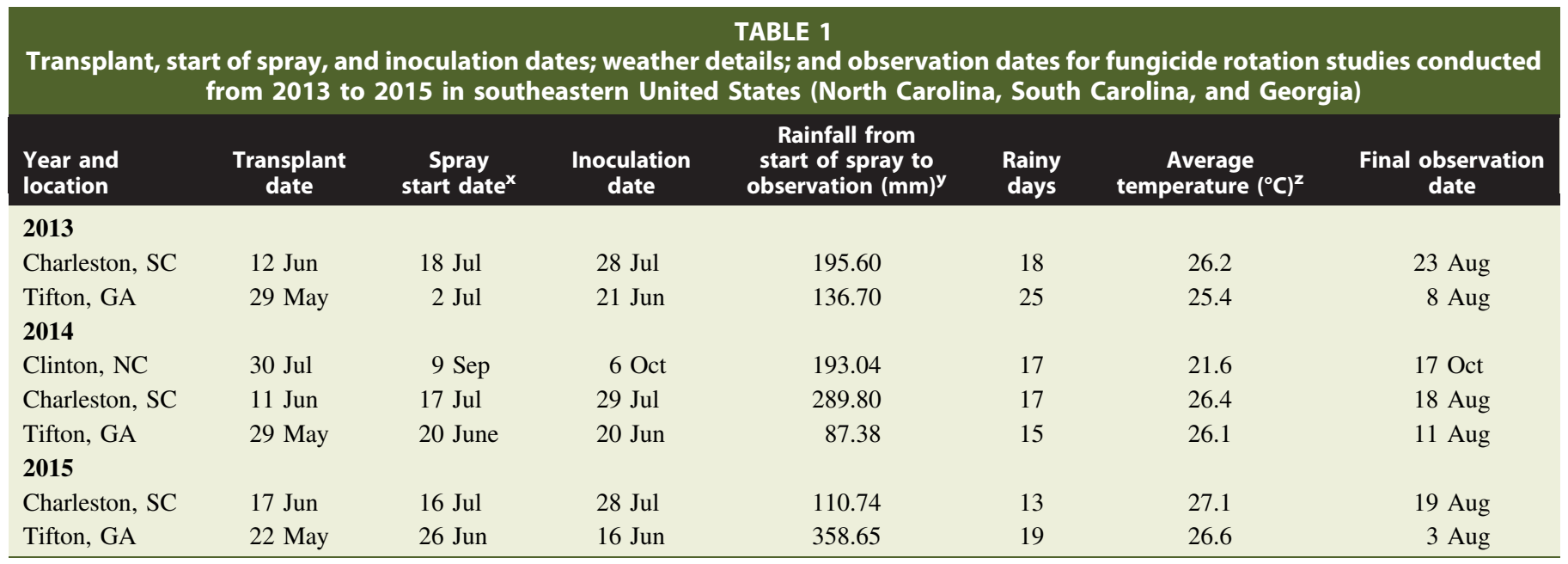

${ }^{\mathrm{x}}$ The date when spray applications for rotation programs were initiated at each location. There were a total of five spray applications at each location and each year.

${ }^{y}$ Number of rainy days from start of spray treatments to observation date. Any precipitation recorded for the day during the period was considered as a rainy day.

${ }^{\mathrm{z}}$ Average temperature from start of spray treatments to observation date. 
TABLE 2

Details of fungicides used in rotation programs for managing Phytophthora fruit rot of watermelon in North Carolina,

\begin{tabular}{|c|c|c|c|c|}
\hline $\begin{array}{l}\text { Trade name and } \\
\text { formulation }^{\mathrm{x}}\end{array}$ & Manufacturer & Active ingredient (a.j) ${ }^{y}$ & FRAC code ${ }^{z}$ & $\begin{array}{l}\text { Application rate } \\
\text { (product/ha) }\end{array}$ \\
\hline Orondis & Syngenta & oxathiapiprolin & U15 & 0.66 liter \\
\hline Actigard 50WG & Syngenta & acibenzolar-S-methyl & P1 & $70 \mathrm{~g}$ \\
\hline Zampro & BASF & ametoctradin/dimethomorph & $45 / 40$ & 1.02 liter \\
\hline Revus 2.08SC & Syngenta & mandipropamid & 40 & 0.59 liter \\
\hline Ranman & FMC Corp. & cyazofamid & 21 & 0.20 liter \\
\hline Presidio 4FL & Valent & fluopicolide & 43 & 0.29 liter \\
\hline K-Phite 7LP & Plant Food Systems & Mono- and dipotassium salts of phosphorus acid & $\mathrm{NC}$ & 2.34 liter \\
\hline
\end{tabular}

${ }^{\mathrm{x}}$ Activator $90(0.1 \%)$ was added to all the Revus treatments and Silwett L-77 to Ranman treatments as per manufacturers instructions.

${ }^{\mathrm{y}}$ The details of the active ingredients including concentrations present in each of the fungicides can be obtained from the appropriate fungicide label.

${ }^{\mathrm{z}}$ FRAC $=$ Fungicide Resistance Action Committee.

treatments were applied: in 2013 on 18 and 25 July, and 1, 8, and 19 August; in 2014 on 17, 24, and 31 July, and 7 and 14 August; and in 2015 on 16, 23, and 29 July, and 7 and 13 August. In Georgia, the fungicide applications were made: in 2013 on 2, 9, 16, 23, and 30 July; in 2014 on 30 June, and 7, 14, 21, and 28 July; and in 2015 on 26 June, and 2, 10, 17, and 24 July. In North Carolina, the fungicide treatments were applied: in 2014 on 9, 18, 23, and 30 September, and 7 October. In 2015 in North Carolina, the experiment was washed out due to severe rains and flooding.

\section{Inoculation of Plots}

Inoculation dates at each location and year are presented in Table 1. To enhance disease development, all the plots were inoculated about two weeks after the start of spray treatments in South Carolina. Each year, mefenoxam-sensitive and -insensitive isolates were grown for a month on rice grains soaked in V8 juice in widemouth mason jars. The isolates were grown individually and mixed prior to uniformly spreading them by hand-scattering (122 grams/plot) in each plot as described previously (Kousik et al. 2011, 2014a). Inoculations were done on days when rain was predicted and conditions were favorable for disease development. In Georgia, additional inoculum of $P$. capsici was applied by inoculating three squash seedlings (Ji et al. 2012) grown between each two watermelon plots on 21 June 2013, 19 June 2014, and 16 June 2015. In North Carolina, plots were inoculated one week after the first fungicide application in 2014 by scattering $P$. capsici-infested millet seed $(150 \mathrm{~g} / \mathrm{plot})$ throughout each plot. Isolates used for inoculation were of different mating type (A1 and A2) and mefenoxam sensitivity (sensitive and insensitive). Overhead irrigation was used immediately before and after inoculation to promote infection in North Carolina. Local isolates were used at each location.

\section{Melcast-Based Fungicide Treatments}

Melcast is a melon-disease forecaster that bases spray applications on Environmental Favorability Indices (EFI) calculated from daily weather data for a given location using periods of temperature and humidity/leaf wetness that are favorable for development of foliar diseases on watermelon and melon (Latin and Egel 2001). Melcast has been used to reduce the number of fungicide applications for management of foliar diseases including gummy stem blight, anthracnose, and Alternaria blight on melon and watermelon (Everts and Shields 2000; Keinath et al. 2007; Latin and Egel 2001). In this study, our objective was to determine if Melcast would help reduce spray applications for management of
Phytophthora fruit rot of watermelon. Unlike the conventional calendarbased sprays, Melcast schedules spray applications based on forecasting for managing foliar diseases in melon and watermelon, such as anthracnose and gummy stem blight (Latin and Egel 2001). For our experiments, we made our first spray application after fruit formation as the watermelon fruit is highly susceptible to $P$. capsici at all stages (Ando et al. 2009; Kousik et. al. 2014b). The Melcast data on EFI for each of the three locations was obtained from the Purdue University website (http://melcast.ceris.purdue.edu). A Melcast threshold of $35 \mathrm{EFI}$ units accumulated over time (days) was considered as the appropriate time to spray, similar to what is used for other foliar diseases including gummy stem blight on watermelon (Latin and Egel 2001). Details of weather conditions for each location and year are provided in Table 1.

\section{Data Recording and Statistical Analysis}

The total number of marketable watermelon fruit and the number of marketable-sized rotten fruit in each plot were recorded at end of the experiment. Details of the final observation dates at each location are presented in Table 1. Total number of fruits and number of rotted fruits per plot were recorded weekly by inserting a field flag through the rotting melon. Fruit rot incidence was calculated as the number of rotted fruit in a plot divided by the total number of fruits in the plot. If the assumptions of homogeneity of variance could not be met the (percent fruit rot) data were transformed to arcsine values and analyzed using Proc GLM procedure of SAS (SAS Institute Inc., Cary, NC). Means were separated using the Fisher's protected Least Significant Difference (LSD, $\alpha=0.05$ ) procedure of SAS. Disease reduction (\%) due to the various fungicide treatments was calculated relative to the mean disease in the nontreated control for each year at each location. Data points for each year and location were used to calculate the mean effectiveness of the various fungicide treatments across years and locations using the percent disease reduction data. Of the five evaluations across years and locations, only the treatments which were evaluated a minimum of four times were included. The two fungicide rotation programs evaluated only in South Carolina for two years were not included. The data was analyzed using the Proc GLIMMIX procedure of SAS and means were separated using the PDIFF option $(\alpha=0.05)$. Location and year were considered as the random variable in the analysis.

\section{Fungicide Rotation Programs and Phytophthora Fruit Rot}

Substantial fruit rot was observed in the nontreated control plots in 2013 in South Carolina (63\%) and Georgia (76\%) (Table 3). All 
TABLE 3

Simple fungicide rotation programs evaluated for managing Phytophthora fruit rot of watermelon in Charleston, SC, and Tifton, GA, in 2013

\begin{tabular}{|c|c|c|c|c|c|c|c|c|c|}
\hline nontreated & nontreated & nontreated & nontreated & nontreated & $63 \mathrm{a}^{\mathrm{z}}$ & - & $76 \mathrm{a}$ & - & - \\
\hline Zampro & K-Phite & Zampro & K-Phite & Zampro & $32 \mathrm{~b}$ & 49 & $61 \mathrm{ab}$ & 20 & 35 \\
\hline Actigard & K-Phite & Revus & Presidio & Presidio & $46 \mathrm{~b}$ & 28 & $60 a b c$ & 22 & 25 \\
\hline Ridomil-Gold & Ridomil-Gold & Ridomil-Gold & Ridomil-Gold & Ridomil-Gold & $40 \mathrm{~b}$ & 37 & $52 \mathrm{bc}$ & 32 & 35 \\
\hline Presidio & K-Phite & Presidio & $\begin{array}{l}\text { Ranman }+ \\
\text { Ridomil Gold }\end{array}$ & Revus & $35 \mathrm{~b}$ & 44 & $46 \mathrm{bc}$ & 39 & 42 \\
\hline Presidio & V-10208 & Presidio & V-10208 & Presidio & $36 \mathrm{~b}$ & 44 & $40 \mathrm{bc}$ & 48 & 46 \\
\hline Presidio & Zampro & Presidio & Zampro & Presidio & $32 \mathrm{~b}$ & 50 & $37 \mathrm{c}$ & 51 & 50 \\
\hline
\end{tabular}

${ }^{\text {w} A l l ~ s p r a y s ~ w e r e ~ a p p l i e d ~ u s i n g ~ a ~} \mathrm{CO}_{2}$-pressurized backpack sprayer on a weekly basis.

${ }^{x}$ Phytophthora fruit rot incidence was calculated by dividing the number of rotten fruits by total fruits in a plot.

${ }^{\mathrm{y}}$ Disease reduction for each treatment was calculated based on mean disease for nontreated control plots for each location.

${ }^{\mathrm{z}}$ Means followed by the same letter within the column for fruit rot SC (\%) and fruit GA (\%) are not significantly different $(\alpha=0.05)$.

the fungicide treatments significantly reduced fruit rot compared with the nontreated control plots in South Carolina. In Georgia, Presidio alternated with Zampro was numerically the most effective treatment and had significantly less fruit rot compared with the nontreated control or Zampro alternated with K-Phite. Ridomil Gold or tank-mixing Ranman and Ridomil Gold also significantly reduced fruit rot compared with nontreated control. Similarly, the rotation of Presidio/K-Phite/Ranman + Ridomil Gold/Revus or Presidio alternated with V-10208 was also effective in reducing fruit rot. Overall, across the two locations in 2013, the maximum disease reduction compared with nontreated control was only $50 \%$, and therefore we evaluated different fungicide rotation programs in 2014 and 2015 across three locations. Since tank-mixing of Ranman and Ridomil Gold did significantly reduce fruit rot compared with nontreated controls at both locations, we included this treatment as a part of fungicide rotation programs in 2014 and 2015.

Substantial fruit rot (mean $=75 \%$ ) was observed in the nontreated control plots at all three locations in 2014 and ranged from 54 to $91 \%$ (Table 4). Across the three locations, the fungicide rotation programs had significantly lower Phytophthora fruit rot incidence compared with nontreated control. The rotation of Zampro alternated with Orondis was numerically the best based on the means across the locations. However, there were no significant differences among the various rotation programs suggesting that any of these rotations has equivalent potential for managing Phytophthora fruit rot. Significant fruit rot $(91 \%)$ was observed in the nontreated control plots in South Carolina. Significant differences $(P \leq 0.0001)$ were observed among the fungicide treatments. All the fungicide rotation programs significantly reduced fruit rot compared with the nontreated control. The standard fungicide treatment of Ridomil Gold was not as effective as some of the other treatments because of the presence of insensitive strains in the field in South Carolina in 2014. Melcast indicated no spray on 31 July, but it did suggest a spray on 1 August. However, we could not get back into the field to make an application until 7 August due to rainy and wet soil conditions for spray treatment. Despite having one less spray treatment, the Melcast scheduled treatments were not significantly different from the other effective fungicide rotations for managing fruit rot. Zampro alternated with Orondis, or Revus with Presidio were very effective in managing fruit rot. The rotation scheme of two sprays of Orondis
(17 July, 14 August) and one of Presidio (31 July) was as effective as other programs despite having two less sprays. Similarly, in North Carolina, severe fruit rot was observed in the nontreated control plots with an average of $80 \%$ of fruit rotten. All rotation programs performed better than the nontreated control. No significant differences among the various rotation programs were observed. In the plots with Actigard followed by Ranman + Ridomil, Presidio, V10208, and a final application of Orondis, no rotten fruit were detected. The standard treatment of Revus rotated with Ridomil Gold also was significantly better than the nontreated control, although not different from other rotation programs. Implementing Melcast did not result in fewer spray applications than a weekly schedule in North Carolina in 2014. The standard Ridomil Gold treatment was also very effective in reducing fruit rot in North Carolina. In Georgia, over 50\% of the fruit were rotten in the nontreated control plots. All rotation programs performed better than the nontreated control. Zampro alternated with Orondis was numerically the best treatment. Melcast did not suggest fewer spray applications than a weekly schedule in Georgia in 2014 and was not significantly different in reducing fruit rot compared with other fungicide rotation programs (Table 4).

Similar trials were conducted at the three locations in 2015 (Table 5). In North Carolina, no data were obtained because the trials were washed out due to severe rains and flooding. The trials were successful in South Carolina and Georgia. Overall, significant fruit rot was observed across the two locations (mean $=58 \%$ ). The simple rotation scheme of Zampro and Orondis was numerically the best treatment at both locations. Significant fruit rot (63\%) was observed in the nontreated control plots in South Carolina (Table 5). Significant differences $(P \leq 0.0001)$ were observed among the fungicide treatments. However, fruit rot in nontreated plots in South Carolina was less in 2015 (63\%) compared with 2014 (91\%). All the fungicide rotation programs significantly reduced fruit rot compared with the nontreated control. Ridomil Gold was not as effective as some of the other treatments likely because of the presence of insensitive strains of the pathogen in the field. Melcast indicated no spray on July 23 and none was applied for that one treatment. Despite one less spray the Melcast-scheduled treatment was not significantly different from the other effective fungicide rotations for managing fruit rot (Table 5). Zampro alternated with Orondis or Revus alternated with Presidio were numerically the 


\section{TABLE 4}

Effect of fungicide rotation programs on development of Phytophthora fruit rot on watermelon at three locations (South Carolina, North Carolina, and Georgia) in southeastern United States in 2014

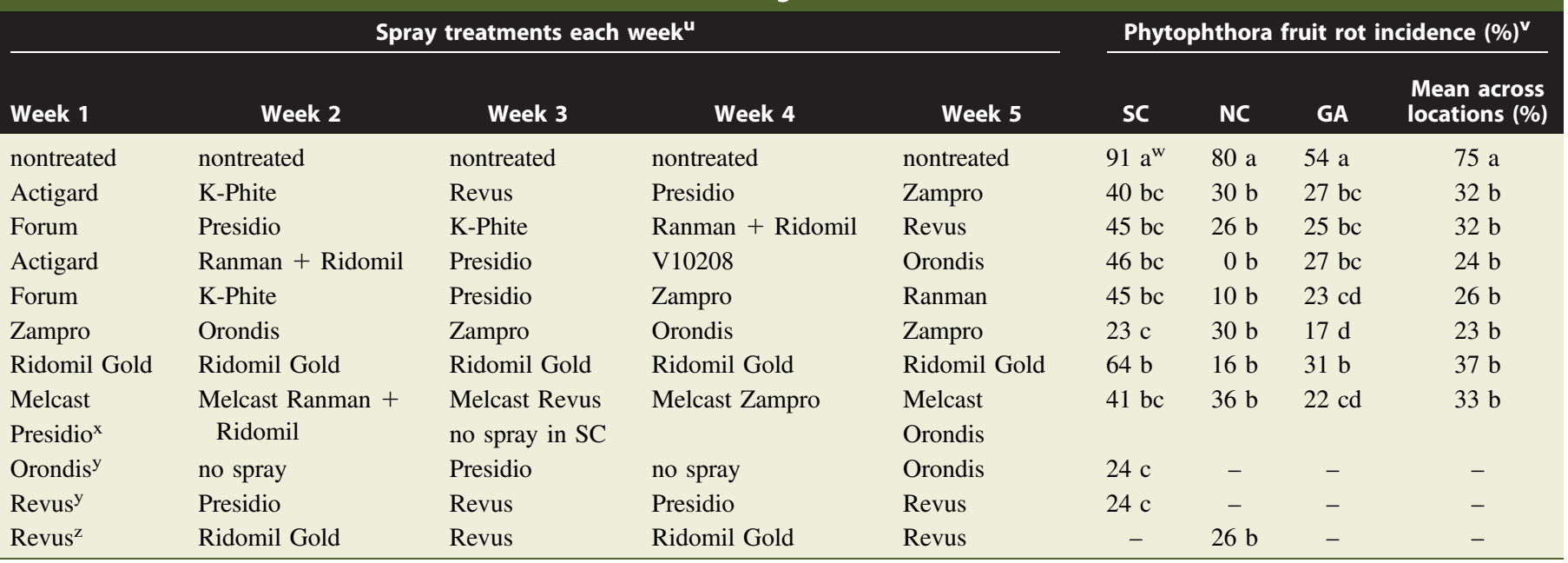

" All sprays were applied using a $\mathrm{CO}_{2}$-pressurized backpack sprayer on a weekly basis.

${ }^{\mathrm{v}}$ Phytophthora fruit rot incidence was calculated by dividing the number of rotten fruits by total fruits in a plot.

${ }^{\mathrm{w}}$ Means followed by the same letter within a column are not significantly different $(\alpha=0.05)$.

${ }^{x}$ Melcast sprays were based on predictions provided by Purdue University for each location in the study. In North Carolina and Georgia, all five sprays were made. However, in South Carolina Melcast indicated no spray on the spray day during the third week. However, it indicated spray for the next day. But this spray could not be made due to heavy rains.

${ }^{y}$ In South Carolina, two extra fungicide rotation programs were evaluated.

${ }^{\mathrm{z}}$ A fungicide rotation program of Revus alternated with Ridomil Gold was also included in North Carolina.

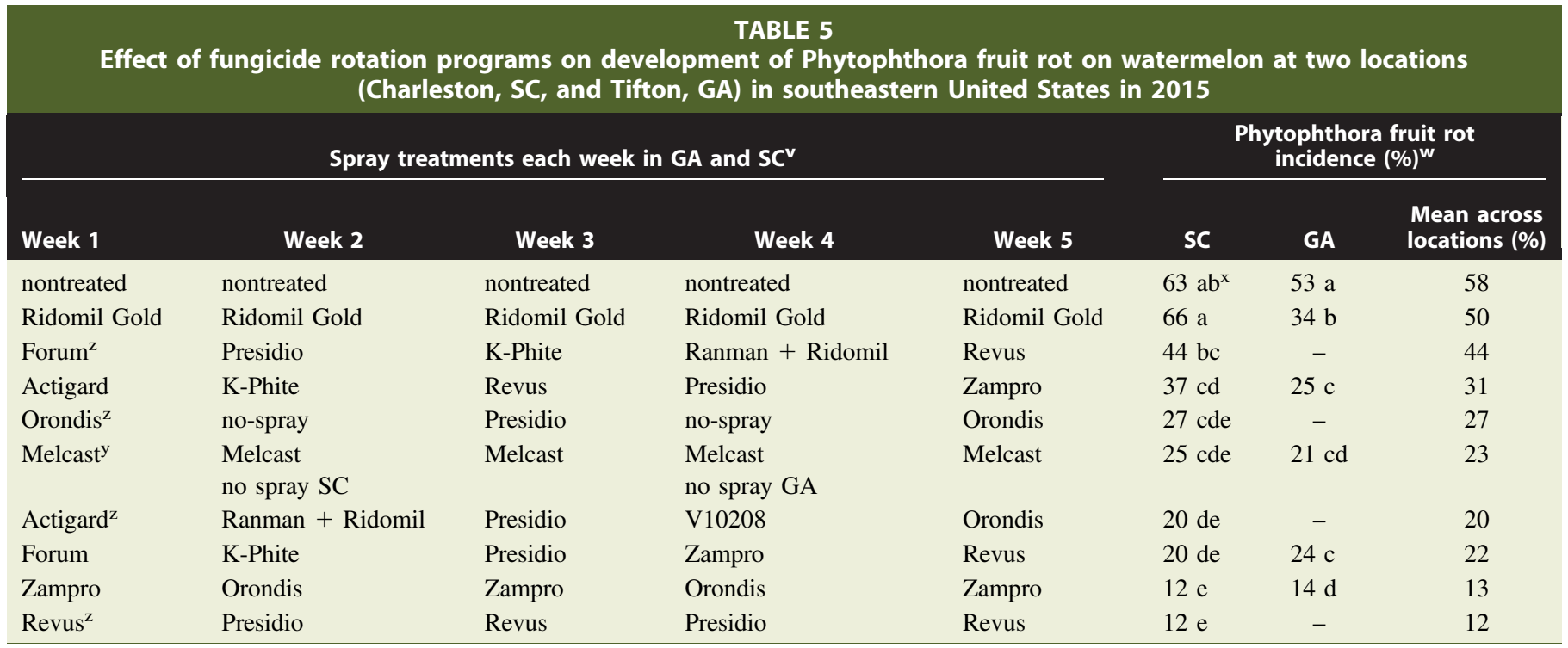

${ }^{v}$ All sprays were applied using a $\mathrm{CO}_{2}$-pressurized backpack sprayer on a weekly basis.

${ }^{w}$ Phytophthora fruit rot incidence was calculated by dividing the number of rotten fruits by total fruits in a plot.

${ }^{x}$ Means followed by the same letter within a column are not significantly different $(\alpha=0.05)$.

${ }^{y}$ Melcast sprays were based on predictions provided by Purdue University for each location in the study. In South Carolina and Georgia, Melcast suggested one less spray. In South Carolina, Melcast sprays were Presidio, no spray, Revus, Zampro, and Orondis. In Georgia, the Melcast sprays were Zampro, Orondis, Presidio, no spray, and Revus.

${ }^{\mathrm{z}}$ In South Carolina, four extra fungicide rotation programs were evaluated similar to 2014

most effective in managing fruit rot. The rotation program of two sprays of Orondis and one of Presidio was as effective as other programs despite two less sprays. However, this rotation scheme was not as effective in 2015 as it was in 2014. In Georgia, over 50\% of the fruit were rotten in the nontreated control plots. All rotation programs performed better than the nontreated control. Zampro alternated with Orondis was the best treatment. Ridomil Gold was significantly better than nontreated control in reducing Phytophthora fruit rot. However, Ridomil Gold was not as effective as Zampro rotated with Orondis or any other rotation programs (Table 5). Melcast indicated no spray application for the fourth week in Georgia and none was applied for that treatment. Despite 
one less spray the fungicide rotation program used in Melcast in Georgia was as effective as the other rotation programs and was not significantly different from Zampro alternated with Orondis (Table 5).

Overall, across the three locations and two years, the fungicide rotation program of Zampro alternated with Orondis was numerically the most effective in reducing Phytophthora fruit rot (Table 6). The fungicide rotation program of Actigard/Ranman + Ridomil Gold/Presidio/V10208/Orondis was as effective as Zampro alternated with Orondis. Overall, the standard Ridomil Gold treatments were numerically the least effective in reducing Phytophthora fruit rot and this was partly due to the presence of insensitive strains. Overall the other rotation programs also reduced Phytophthora fruit rot by over $50 \%$ across years and locations (Table 6).

Using Melcast to determine when to apply fungicides did not significantly affect control in all three situations where one spray treatment was reduced. In these studies we used one threshold and started our spray applications on the same day as our other fungicide rotation programs, unlike what is recommended by Melcast for other diseases such as gummy stem blight and anthracnose of watermelon (Keinath et al. 2007; Latin and Egel 2001). Melcast suggested reducing one spray treatment in two out of the five trials: one in South Carolina and one in Georgia. In the third, Melcast suggested a spray the next day after the scheduled calendar-based spray date in South Carolina in 2014; however, a spray treatment was not applied owing to excessive rains that created difficult field conditions. Melcastsuggested sprays were not consistently effective in reducing spray applications and Phytophthora fruit rot across locations. Further studies to evaluate various Melcast EFI thresholds may make this disease-forecasting tool more suitable for reducing spray treatments for effective management of Phytophthora fruit rot of watermelon.

\section{Conclusions and Management Implications}

Development of pathogen resistance to fungicides is a major concern for manufacturers and growers and hence rotation programs or tank mixing of fungicides from different FRAC groups (Fungicide Resistance Action Committee) (Table 2) are recommended. Fungicides that were effective for managing Phytophthora fruit rot of watermelon have been identified in previous studies (Kousik et al. 2011, 2014a). The present study was undertaken in three locations to evaluate fungicide rotation programs for managing Phytophthora fruit rot in the southeastern United States. The study has resulted in the identification of several fungicide rotation programs that significantly reduce Phytophthora fruit rot. Overall, the rotation of Zampro alternated with Orondis were numerically the most effective across locations and years. Similarly, the rotation of Revus alternated with Presidio in South Carolina was also effective and disease reduction was $78 \%$ over two years. However, both these were relatively simple programs and may lead to overuse of one of the fungicides. The rotation of Actigard/Ranman+ Ridomil Gold/ Presidio/V10208/Orondis was equally effective and utilized fungicides from six different FRAC groups. Complex rotations utilizing fungicides from different FRAC groups has greatest potential to prevent resistance development in the pathogen. In addition, tankmixing fungicides from two different groups for one of the spray applications can also be expected to be effective. Utilizing tank mixes with different FRAC groups in rotation programs with fungicides from other groups should also be an effective strategy. Application of the systemic resistance activator Actigard during early stages of plant growth may also be helpful. Similarly, Forum and K-Phite can be applied early in the rotation programs, as they are less expensive but not as effective as some of the other new fungicides. This study also demonstrates that fairly flexible fungicide rotation programs can be developed for use by growers, depending upon the availability of the fungicides.

Orondis (formerly known as DPX-QGU 42, OXTP, or Zorvec in Europe) is a relatively new fungicide in the U.S. market. However, Orondis has restrictions with respect to number of applications per season. Only two foliar applications per season are allowed. We found that the rotation of three applications of Zampro and two of Orondis was one of the most effective treatments and would be allowed per label directions. However, it will be prudent to continue to evaluate other rotation programs for effective management of Phytophthora fruit rot and for extending the usefulness of the fungicides. Growers should keep in mind that it is very important to rotate among the fungicides to prevent development of resistance in the pathogen population to these fungicides. Growers should not rotate Revus and Forum in sequence as they both belong to FRAC group 40 and have similar modes of fungicidal action. Similarly, Zampro also contains the same active ingredient (dimethomorph) as

\begin{tabular}{|c|c|c|c|c|c|c|c|c|c|c|}
\hline Phytophtho & fruit rot redu & $\begin{array}{l}\text { on due to fun } \\
\text { Carolina) }\end{array}$ & $\begin{array}{l}\text { icide rotation pro } \\
\text { n southeastern Ur }\end{array}$ & $\begin{array}{l}\text { LE } 6 \\
\text { rams across } t \\
\text { ited States in }\end{array}$ & $\begin{array}{l}\text { ee lo } \\
014\end{array}$ & $\begin{array}{l}\text { tions ( } \\
\text { d } 201\end{array}$ & ieor & So & aro & , and North \\
\hline & Spray treatm & nts each week i & 2014 and $2015^{x}$ & & & ease re & luction & ompare & I with $\mathrm{C}$ & ntrol $(\%)^{y}$ \\
\hline Week 1 & Week 2 & Week 3 & Week 4 & Week 5 & SC14 & SC15 & GA14 & GA15 & NC14 & $\begin{array}{l}\text { Mean across } \\
\text { years and } \\
\text { locations (\%) }\end{array}$ \\
\hline Forum & K-Phite & Presidio & Zampro & Revus & 50 & 68 & 57 & 54 & 88 & $66 a b$ \\
\hline Melcast & Melcast & Melcast & Melcast & Melcast & 55 & 60 & 59 & 61 & 55 & $60 a b$ \\
\hline Actigard & K-Phite & Revus & Presidio & Zampro & 56 & 41 & 50 & 52 & 63 & $55 \mathrm{bc}$ \\
\hline Forum & Presidio & K-Phite & Ranman + Ridomil & Revus & 50 & 29 & 54 & - & 68 & $52 \mathrm{bc}$ \\
\hline
\end{tabular}

${ }^{\mathrm{x}}$ All sprays were applied using a $\mathrm{CO}_{2}$-pressurized backpack sprayer on a weekly basis.

${ }^{y}$ Disease reduction for each treatment was calculated based on mean disease for nontreated control plots for each location.

${ }^{\mathrm{z}}$ Means followed by the same alphabet are not significantly different $(\alpha=0.05)$. LSmeans represented are those calculated using the Proc GLIMMIX procedure of SAS. 
Forum. Hence, care should be taken while rotating these fungicides. We developed the above-described fungicide rotation programs with the intent of preventing or delaying development of resistance in the pathogen population. In addition, products such as Orondis (e.g., Orondis Ultra) may be combined with other fungicides, including Revus (mandipropamid, FRAC group 40), by the manufacturers. This should also be taken into account when selecting fungicides for a rotation.

Melcast has been used to reduce the number of fungicide applications for management of gummy stem blight on watermelon (Everts and Shields 2000; Keinath et al. 2007). In the present study, Melcast helped reduce one spray treatment in essentially three of the five experiments and the disease levels were not significantly different from other fungicide rotation programs. However, in this study, the first spray application was initiated after fruit formation, unlike conventional Melcast where initial sprays of a protectant fungicide are recommended early in the plant growth stages soon after planting. Melcast was initiated after fruit formation because the fruits are the part of the watermelon plant most susceptible to $P$. capsici. Further studies with modified Melcast thresholds and earlier sprays with systemic fungicides may be needed to effectively use Melcast recommendations for scheduling sprays to manage Phytophthora fruit rot.

In previous studies conducted in South Carolina, we have shown that some of the fungicides (e.g., Orondis, Zampro, Revus alternated with Presidio) were effective in reducing postharvest fruit rot by 80 to $92 \%$ for up to 9 days after the last spray in the field where the incidence ranged from 18 to $36 \%$ (Kousik et al. 2014a). Hence in these trials, for most of the rotation programs, the last spray was either Orondis, Zampro, Revus, or Presidio. However, we did not attempt to study effectiveness of the postharvest disease reduction due to the rotation programs as such facilities were not available at all the three locations. In the trials conducted at the three locations, the disease pressure was extreme because we had inoculated the plots to induce development of Phytophthora fruit rot. This was probably the reason for not achieving $100 \%$ reduction in disease. Fruit rot incidence in some of the numerically most effective fungicide rotation programs were fairly high (12 to 23\%) and may not be acceptable to some growers. However, in many instances the growers may not face the extreme conditions created in our studies to generate disease and may get more effective disease management, especially if they use an integrated approach. As has been previously reported (Kousik et al. 2011, 2014a; McGrath 1996), under favorable weather conditions and severe disease pressure it can be extremely difficult to effectively manage Phytophthora fruit rot. Therefore, it is essential that growers use an integrated approach (Babadoost 2004; Ji et al. 2012; Ristaino and Johnston 1999), which includes proper site selection, well drained fields, crop rotation, and fungicides to effectively manage this disease.

\section{Acknowledgments}

We acknowledge the technical assistance of Jennifer Ikerd, Kim Alford, Lance Lawrence, Andrew Price, Simeon Hallman, Taylor McLaughlin, Tyler Grespin, Michael Adams, and Camilo Parada in conducting many of these experiments. The authors also wish to acknowledge Drs. W. P. Wechter and $\mathrm{P}$. Wadl for critical review of the manuscript. This work was supported in part by a grant from the National Watermelon Association (NWA). NWA did not take part in planning, in conducting, or in any other aspect of this study including submission of this manuscript. Mention of a trademark name or proprietary product does not constitute a guarantee or warranty of the product by the U.S. Department of Agriculture Agricultural Research Service (USDA ARS), nor does it imply exclusion of other products that may also be suitable. USDA is an equal opportunity provider and employer.
Literature Cited

Ando, K., Hammar, S., and Grumet, R. 2009. Age-related resistance of diverse cucurbit fruit to infection by Phytophthora capsici. J. Am. Soc. Hortic. Sci. $134: 176-182$.

Babadoost, M. 2004. Phytophthora blight: A serious threat to cucurbit industries. APS Feature, American Phytopathological Society, St. Paul, MN.

Erwin, D. C., and Riberio, O. K. 1996. Phytophthora Diseases Worldwide. American Phytopathological Society, St. Paul, MN.

Everts, K. L., and Shields, P. L. 2000. Evaluation of fungicides for control of gummy stem blight and leaf blight on watermelon. Fungic. Nematic. Tests 55:287.

Granke, L. L., Quesada-Ocampo, L., Lamour, K., and Hausbeck, M. K. 2012. Advances in research on Phytophthora capsici on vegetable crops in the United States. Plant Dis. 96:1588-1600.

Hausbeck, M. K., and Lamour, K. H. 2004. Phytophthora capsici on vegetable crops: Research progress and management challenges. Plant Dis. 88: 1292-1303.

Jackson, K. L., Yin, J., and Ji, P. 2012. Sensitivity of Phytophthora capsici on vegetable crops in Georgia to mandipropamid, dimethomorph, and cyazofamid. Plant Dis. 96:1337-1342.

Ji, P., Koné, D., Yin, J., Jackson, K. L., and Csinos, A. S. 2012. Soil amendments with Brassica cover crops for management of Phytophthora blight on squash. Pest Manag. Sci. 68:639-644.

Keinath, A. P. 2007. Sensitivity of populations of Phytophthora capsici from South Carolina to mefenoxam, dimethomorph, zoxamide and cymoxanil. Plant Dis. 91:743-748.

Keinath, A. P., Everts, K. L., Langston, D. B., Egel, D. S., and Holmes, G. J. 2007. Multi-state evaluation of reduced -risk fungicides and Melcast against Alternaria leaf blight and gummy stem blight of muskmelon. Crop Prot. 26:1251-1258.

Kemble, J. M. 2015. Pages 102-105 in: 2016 Vegetable Crop Handbook. Southeastern Vegetable Extension Workers, Southeastern, U.S.

Kousik, C. S., Adams, M. L., Jester, W. R., Hassell, R., Harrison, H. F., and Holmes, G. J. 2011. Effect of cultural practices and fungicides on Phytophthora fruit rot of watermelon in the Carolinas. Crop Prot. 30:888-894.

Kousik, C. S., Brusca, J., and Turechek, W. W. 2016. Diseases and disease management strategies take top research priority in the Watermelon Research and Development Group members survey (2014 to 2015). Plant Health Prog. 17:53-58.

Kousik, C. S., Ikerd, J., Wechter, W. P., Harrison, H., and Levi, A. 2012. Resistance to Phytophthora fruit rot of watermelon caused by Phytophthora capsici in U.S. plant introductions. HortScience 47:1682-1689.

Kousik, C. S., Ikerd, J. L., and Harrison, H. F. 2014a. Development of pre- and postharvest Phytophthora fruit rot on watermelons treated with fungicides in the field. Plant Health Prog. 15:145-151.

Kousik, C. S., Ikerd, J. L., and Turechek, W. W. 2014b. Pages 35-37 in: Fruit age and development of Phytophthora fruit rot on resistant and susceptible watermelon lines. Cucurbitaceae 2014 Proceedings. American Society for Horticultural Science, Alexandria, VA.

Kousik, C. S., and Keinath, A. P. 2008. First report of insensitivity to cyazofamid among isolates of Phytophthora capsici from the southeastern United States. Plant Dis. 92:979.

Kousik, C. S., Ling, K., Adkins, S. T., Webster, C. G., and Turechek, W. 2014c. Phytophthora fruit rot-resistant watermelon germplasm lines: USVL489PFR, USVL782-PFR, USVL203-PFR, and USVL020-PFR. HortScience 49:101-104.

Lamour, K. H., and Hausbeck, M. K. 2000. Mefenoxam insensitivity and the sexual stage of Phytophthora capsici in Michigan cucurbit fields. Phytopath. 90:396-400.

Latin, R., and Egel, D. S. 2001. MELCAST: Melon disease forecaster. Purdue University Coop. Ext., West Lafayette, IN. https://www.extension.purdue. edu/extmedia/BP/BP-64-W.pdf

McGrath, M. T. 1996. Phytophthora Fruit Rot. Pages 53-54 in: Compendium of Cucurbit Diseases. T. A. Zitter, D. L. Hopkins, and C. E. Thomas, eds. APS Press, St. Paul, MN.

Morrissey, B. 2006. NWA Update. The Vineline. April 2006:7-10.

Parra, G., and Ristaino, J. B. 2001. Resistance to mefenoxam and metalaxyl among field isolates of Phytophthora capsici causing Phytophthora blight of bell pepper. Plant Dis. 85:1069-1075.

Ristaino, J., and Johnston, S. 1999. Ecologically based approaches to management of Phytophthora blight of bell pepper. Plant Dis. 83: 1080-1089.

Sanders, D. C. 2006. Vegetable Crop Handbook for the Southeastern U.S. The Packer, Lenexa, KS. 